\title{
Sexo, reprodução, amor e erotismo
}

Amparo Caridade ${ }^{1}$

"Para os gregos clássicos, o corpo era o locus de uma beleza idealizada; para os primeiros sexólogos, influenciados pela visão mecanicista da ciência, o corpo era uma máquina de prazer-dor. em nossa própria era de uma capitalismo consumista, o corpo é mercadoria sexualizada”.

Highwater

As palavras estão relacionadas a contextos significativos. Sexo, por exemplo, vem do verbo latino "secare" que significa "cortar", "separar". Araguari (1) acha que o termo sexo foi utilizado para uma abordagem mais biológica, sendo um conceito limitado. De fato, desde o século XIX, o vocábulo refere-se às relações físicas entre os sexos, "fazer sexo". Com a necessidade de uma conceituação mais ampla, surgiu o termo "sexuali-

1. Psicóloga. 
dade" que não é um fenômeno primordialmente natural, mas antes um produto de forças sociais e históricas, e que inclui, além do biológico, o impulso e a emoção que o sexo pode produzir. Reprodução, erotismo e amor, também se contextualizam em meio as concepções originárias dos seres humanos e seus valores, quase sempre expressos por mitos. São termos estreitamente vinculados às origens e significados do existir humano.

Pensando na origem dos seres vivos, F. Jacob (2) faz uma analise a respeito das vantagens e dos inconvenietes do processo de reprodução sexuada e assexuada, e questiona por que há de ser preciso juntarem-se dois para fazer um terceiro. Por que é que de todas as funções do cropo, somente a reprodução é assegurada por um órgão de que um indivíduo possui uma metade, o que obriga a gastar muito tempo e energia para encontrar a outra metade. Na origem a reprodução é assexuada, e muitos organismos não têm sexo, reproduzem-se por cissiparidade ou gemulação. Um só organismo é suficiente para produzir dois idênticos. Por que os animais e as plantas devem acasalar-se para chegarem ao mesmo resultado? Passamos por tanto trabalho para juntar nossos genes aos de um outro para estarmos seguros de que o nosso filho será diferente de nós mesmos e de nossos outros filhos. $\mathrm{O}$ autor parece responder a esta questão da escolha mais complexa para a reprodução, com o fato de que a junção de dois possibilita o surgimento de um terceiro que é diferente de ambos. O sexo torna-se então essa máquina de fazer o diferente.

A partir desse complicado intercâmbio questiono aonde pode conduzir-nos, o termos sido feitos suficientes em se tratando da reprodução a da sexualidade? Por que somos precisantes de um outro? Que conseqüências isso traz ao existir? A dimensão biológica não é suficiente para explicar a sexualidade humana. Precisamos da função simbólica da linguagem para penetrar na estrutura complexa do relacionamento sexual do Homo Sapiens, totalmente dependente de seus mitos a valores.

O Banquete, em Platão (3), narra o mito da origem dos seres humanos e do amor. Segundo esse mito, os homens tinham, na sua origem, órgão duplos, formas arredondadas, quatro mãos, quatro pernas, dois órgãos de geração, duas faces, quatro orelhas e uma só cabeça. Havia três sexos distintos que correspondiam ao masculino, ao feminino e ao andrógino, que participava do masculino e do feminino. $\mathrm{O}$ masculino vinha do sol (Hélio), o feminino, da terra (Géia) e o andrógino, da lua (Selene). Os humanos eram redondos como os astros, seus progenitores, o que os tornava robustos e muito velozes. Também eram muito audaciosos e um dia resolveram alçar aos céus e atacar os deuses. Zeus, enfurecido, enfraqueceu-os, dividindo-os ao meio. Diz o mito que, a partir de então, cada metade pôs-se à procura da outra. Seus órgãos que antes era posteriores e só podiam fecundar com a terra, foram colocados na frente e começaram a procriar entre si, homens e mulheres. Em relação ao amor isso difexia, porque o encontro de uma metade com qualquer outra, dava um estado de 
felicidade. Mesmo assim, isso não correspondia ao estado de plenitude anterior, de seres integrados na sua totalidade. Essencialmente o homem ficou sendo um ser dividido e incompleto, desejante de um objeto capaz de resgatar-lhe a integridade. Permanecemos seres da falta.

Homens a mulheres, somos hoje essas metades ambulantes, desejantes de totalidade. Este é um sonho andrógino, e dele nos aproximamos pela vivência sexual, quando machos e fêmeas rendemo-nos aos nossos limites e nos deixamos "completar", fundir, superar, por breves instantes orgásticos. Em torno dessa façanha, proliferam inúmeros discursos, mas como o desejo nunca é satisfeito, porque não existe um objeto capaz disso, também esses discursos jamais se esgotam, e a verdade sobre o desejo jamais se totaliza. É por isso que, repetidamente, falamos e escrevemos sobre sexo, reprodução, erotismo e amor. São temas que nos definem como animais humanos.

A dualidade sexual apontada por F. Jacob, tem conseqüências especiais no relacional humano. $\mathrm{O}$ fato é que, nossa incompletude, não apenas biológica, fatalmente nos remete ao outro, e buscá-lo torna-se o destino. Desde o mito da origem, a vacuidade gerada pela falta do outro, provoca uma caçada silenciosa, uma busca ilimitada desse outro. Resultamos em seres pulsionais marcados pelo desejo, acima de tudo, pelo desejo de ser desejados. É o que canta Caetano Veloso: "Pois quando eu te vejo, eu desejo o teu desejo". Isso nos atormenta e também nos aproxima da possibilidade de preenchimento da falta primordial, de seres cindidos porque, só o desejo de um outro humano nos refaz.

Nesse relacional, procriar não se torna meta para todos os indivíduos. Existem pessoas que por motivos diversos, não se propõem a ter filhos. Se remontarmos à história, compreenderemos que a humanidade oscilou desde a necessidade de se gerar filhos para a multiplicação da mão de obra para o trabalho, ou para o serviço militar, até a necessidade atual de se fazer um controle reprodutivo, já que a superpopulação constitui uma das ameaças contemporâneas. Saímos pois da necessidade para a possibilidade, para a liberdade de procriar. Isso muda em muito o sentido das coisas. Ter um filho hoje deve ser tanto a expressão do desejo do indivíduo, como a resultante análise de condições sócio-econômicas para fazê-lo. Procriar hoje, deve ser um ato pensado, desejado, significativo, não apenas um ato cumprido. $\mathrm{O}$ contraceptivo viabilizou essa revolução tão necessária ao espírito humano, sobretudo ao feminino que, felizmente, já tem condições de não submeter-se à idéia da fatalidade biológica de procriar.

Procriar implica na noção da mortalidade. Prever a descendência, é também reconhecer o efêmero da passagem. Porque somos racionais, ternos consciência da morte, e por ter essa consciência, a recusamos. Queremos a imortalidade, buscamos meios de nos perturbar. A paternidade/maternidade é a grande tentativa humana de superação da finitude, uma busca de imortalização, e a mais clara recusa da morte. 
A prontidão psicológica para procriar supõe a lida do indivíduo com seu desejo. Somos seres do desejo, e desejar ter ou não um filho faz muita diferença. Esse desejo marca profundamente as relações que se estabelecerão entre o pai, a mãe e a criança. As coisas ficarão mais positivas e significativas, se a criança for desejada a puder ser benvinda ao mundo. São essas relações primeiras que vão estruturar o emocional do futuro adulto.

A Antropologia revela uma grande variação cultural frente a procriação. Essa variação oscila de acordo com cada grupo étnico, com a época vivida e os costumes adotados. Isso está exemplificado por Elizabeth Banditer em seu livro: Um Amor Conquistado - O Mito do Amor Materno. (4) É curioso observar, que um livro polêmico como esse, surgiu exatamente na França, país notadamente ambivalente frente ao sentimento procriativo. No livro, Banditer defende a tese de que o amor materno não é um sentimento inato, mas um sentimento que se desenvolve ao sabor das variações culturais e sócio-econômicas da história, podendo portanto ser incerto e frágil. É claro que um livro assim, semeador de dúvidas, questionador de uma certeza arraigada ao arquetípico, inquieta, ameaça, deixa em desamparo os filhos de Eva. O fato é que alguns dados de seu trabalho, fundamentam questionamentos feitos por ela: em 1780, de 21.000 crianças, menos de 1.000 eram amamentadas, 1.900 viviam nas casas das amas de leite, e 1.000 tinham uma casa. Muitas crianças morriam na casa das amas, e no mais das vezes os pais siquer iam ao enterro. Banditer pergunta pelo "amor inato" destes pais. Nessa análise a autora considera o amor materno como uma construção cultural que não pode ser confundido com instinto materno.

Contudo o sexo está para além da simples reprodução. Sua importância pode ser facilmente detectada numa rápida visualização teórica. E curioso observar, como são os autores que alcançam mais fundo a questão humana, que dão ênfase maior à força e à importância da sexualidade, do erotismo, e do amor, na vida das pessoas. Mostram como essas dimensões são básicas à vida e à existência humana, e como elas possibilitam sermos nós mesmos e irmos além de nós mesmos. Freud é um desses estudiosos da intimidade humana, que persegue a compreensão do desejo, fazendo incursões pelo inconsciente do indivíduo, lá, onde reside o mistério, o desconhecido, o quase inacessível, o que nos escapa. Para ele, o sexual não se ancora apenas no evidente, no genital, na mecânica das diferenças, mas também no emaranhado de emoções, sensações, anseios e sentimentos que o sexo potencializa. O sexual está na sedução, no olhar que atinge e que adivinha o desejo do outro, no toque (quase sem querer), na fantasia, no afeto, na poética, na metáfora, como no alvoroço da anatomia face ao objeto desejado: aí ela se excita, se faz apta, se revela disponível, ávida de cópula, de troca, de fusão e partilha, de democracia de gestos e intimidades. É real e simbólico esse discurso do orgânico prestes ao prazer, sentimentos à flor da pele e da razão, falência da lógica, vitória do abandono. O corpo é o possibilitador da experiência; 
quando ele é negado, cria-se o discurso da perversão, porque a sexualidade não encontra o seu caminho natural. A sexualidade realiza-se na corporeidade, em completa sintoma com o psiquismo.

Foi a psicanálise que favoreceu o salto qualitativo do olhar mantido sobre o sexo, deslocando a referência, do instinto para a pulsão. Freud evidenciou a sexualidade no que ela difere da procriação, no que ela transpõe o genital, no que ela se torna uma invenção do espírito humano. Isso possibilitou que as pessoas vivessem sua sexualidade independentemente da reprodução. A sexualidade agora é colocada também a serviço do prazer, do bem estar emocional das pessoas. Vista assim, pela ótica da pulsão, a sexualidade é regida pelo desejo, não pelo instinto. Este, opera num regime de circularidade fechada. Quando o corpo precisa de algo, é impelido a agir para obter o que lhe falta, mas o faz por caminhos pré-traçados em direção ao seu objeto, que também é pré-estabelecido. Mesmo assim, no corpo humano, o nível sígnico etológico não se encerra nessa circularidade plena. "O homem é animal que porta a possibilidade, o poder, e o dever ético de ascender ao funcionamento correto da ordem simbólica." (5) Enquanto ser da possibilidade, o homem tem aberto o objeto sexual, que no caso, se dissocia da ordem biológica da reprodução. Esse prazer dissociado do procriativo fica evidente, quando entramos em devaneio ao ler um poema, quando somos olhados com sedução, ou quando observamos o bebê que acaba de mamar e suga a chupeta. O chupar o seio lhe dá um prazer além da ingestão do leite e da conservação do corpo. Isso já é da ordem do regime pulsional.

A pulsão visa, não a satisfação da necessidade, mas ao prazer. É por puro prazer que o bebê continua a sugar mesmo que esteja satisfeito. A pulsão é um "Fator que impulsiona o sujeito na direção do objeto". (6) Ela atua como uma força constante, porque diferentemente do instinto, há algo nela que não se esgota e continua exercendo pressão. Ela torna-se representação, porque o psiquismo se compõe de representações, e o sujeito emerge quando algo do real consegue se fazer representar no campo do simbólico. E neste sentido que o conceito de pulsão determina a especificidade do sujeito.

$\mathrm{O}$ corpo funciona segundo leis e ordens estabelecidas, mais ou menos fixas, mas que são passíveis de perturbações e modificações resultantes de outro nível de funcionamento da pessoa. Muitas vezes o desempenho sexual está impedido nas pessoas, mesmo quando nelas está estabelecida a ordem corporal. Registros da ordem do simbólico, procedentes do educacional, do religioso, do experiencial, do traumático, do relacional, podem estar se interpondo em prejuízo do exercício sexual. Assim, concepções negativas internalizadas acerca do sexo, considerando-o como pecado, coisa feia, perigosa ou nojenta, podem impedir a entrega necessária à experiência amorosa.

É por ser dessa dualidade de ordens, do instinto e da pulsão, do biológico e do psíquico, do animal e do humano, do real e do simbólico, que a sexualidade assume tanta importância na vida do indivíduo. Por ela 
tornamo-nos animais humanos com pretensões divinas, porque é nessa pluralidade de ordens e dimensões que o humano se supera e fere os limites da finitude. Por isso quando polarizamos a sexualidade em uma dimensão exclusiva, fazemos reduções e empobrecimentos. Sexo, é apelo de totalidade não de dicotomização. Bataille torna claro que uma dimensão conduz à outra: "O animal abre em mim uma profundidade que me atrai e que me é familiar. Essa profundidade, num certo sentido, eu a conheço: é minha." (7) $\mathrm{O}$ autor parece dizer que a superação do animal em nós, supõe a plena vivência da própria animalidade. Quando ela é negada, há uma exasperação do desejo e uma exaltação das partes animais. Não podemos contudo coagular nessa dimensão. A condição animal, biológica, é necessária mas não suficiente. Como seres de possibilidades, somos capacitados a fluir para além de nós mesmos.

O erotismo pode ser o grande caminho da superação, porque, ao contrário do que se pensa, ele é uma dimensão da interioridade da pessoa, não de sua exterioridade, do seu visual. O externo, apenas evoca esse interior. “... o que entra em jogo é freqüentemente um aspecto indivizível, não uma qualidade objetiva dessa mulher, que talvez não tivesse, se ela não nos tocasse o ser interior, nada que nos forçasse a escolhê-la" (8). É que a concretização do erotismo visa exatamente atingir esse mais íntimo do ser. O erótico implica numa procura psicológica independente do fim natural da reprodução. Por aí se vê que ele é da ordem do desejo, da pulsão, não da ordem do instinto. Por aí também se compreende que só os homens são eróticos em sua atividade sexual. Enquanto um aspecto da interioridade do indivíduo, o erotismo é mais metáfora que evidência, mais simbólico que real. Mas Bataille lembra que a sexualidade nos homens, não é necessariamente erótica. Ela só o é, quando não for rudimentar, quando não for simplesmente animal. A escolha humana se diferencia do animal, exatamente porque o homem apela para uma mobilidade interior, infinitamente complexa.

Valença (9) também situa o erotismo, na intersecção do humano com o animal. Enquanto aspecto fundamental do humano ele é um além de si, diz ela, e critica a identificação do erótico/sexo-visual, feita pela mídia, em cuja representação predomina o visível que nutre o voyeurismo da cultura. No contexto de mostrar-revelar, diz ela, o corpo absorve o fetiche que caracteriza a mercadoria. Na verdade a imagem exerce fascínio. Se corresponder à realidade, serve ao desejo humano. Do contrário, gera profunda decepção, porque o produto é vendido pela embalagem, não por seu conteúdo. A expressão "loraburra" de Gabriel (o pensador), mostra a confusão da essência com a aparência, bem típica dessa cultura que valoriza a superfície, a maquilagem, em detrimento da interioridade. Por tudo isso acontece a morte da sedução, porque seduzir é um jogo à distância, que a excessiva proximidade compromete. Não se seduz o que está muito próximo, colado, evidenciado, exposto. “... a sedução começa quando o outro é posto 
como desejo, mas por vias e desvios que lhe escapam, e que atravessam a área de inconsciente por onde ele "foge" e escapa de si mesmo". (10)

O caminho epistemológico para estudar o erotismo, transpõe o paradigma positivista. Não se pode falar dele permanecendo no concreto, diz Valença. Bataille já se defrontava com essa questão, e dizia que, ao falar de uma experiência interior como é o erotismo ele não podia fazê-lo como cientista, porque o erótico transpõe o científico, está para além de qualquer teoria. Como o erotismo, o amor também escapa de conter-se em qualquer paradigma. É na representação que ele pode ser tangenciado. É na dimensão simbólica, própria da linguagem, que o amor se deixa anunciar. Por isso, dele falam melhor os poetas e os filósofos.

O Banquete, de Platão, é um elogio ao amor. Mas para debater esse tema, nem mesmo Sócrates falou por si só, preferindo invocar Diotima, sua inspiração, a quem questionava mentalmente: o que seria o amor? E ela responde: “...um meio-termo entre mortal e imortal". Seguidamente questionada, ela diz ainda: "Um grande espírito Sócrates: realmente, todo espiritual situa-se entre o divino e o mortal... o amor nunca está na miséria e nunca na opulência. Também fica a meio caminho entre o saber e a ignorância". (11) Assim, Sócrates, através de Diotima, deixa a questão no ar, ficando sem resposta concreta a grande interrogação humana. As coisas nesse terreno são da ordem do indefinível. Certamente do imaginário humano. A imaginação para Bachelard, não é apenas a faculdade de formar imagens da realidade, mas de "...formar imagens que ultrapassam a realidade, que cantam a realidade. É uma faculdade de sobre-humanidade" (12).

É dessa faculdade de sobre-humanidade que falam poetas e apaixonados. E dizem eles que o amor mora em nós em estado de "emoção inaugural", que seria a sensação de ser eterno no provisório. Que esse amor é "uma corrida apressada até o fim e o mais alto do outro". Que a grandeza do amor está na impossibilidade de catalogá-lo, cristalizá-lo, definí-lo, porque ele está sempre "além de onde o colocamos". Que ele "não é vitória, é descoberta! É funda afinidade inexplicável". Que o amor maduro "É mais definido, colorido e poetizado", que vive os problemas da felicidade, porque na felicidade está o "encontro de peles"... (13) Quem vive o amor sabe do alvoroço existencial que ele causa, da deliciosa inquietação que ele promove, do espreguiçamento espiritual que dele resulta. Encantados, até nos tornamos "inadvertidos poetas da simplicidade" (14). E embora se fale de algo indefinível, há sugestão de infinito quando se tangencia esse desconhecido, que assimilamos em sucessivas gotas de espanto e encantamento.

Roland Barthes, outro ser enfeitiçado pelo amor, fala da "doçura do abismo", onde sob efeito de uma fusão ..."morremos juntos de tanto amar". É no terreno da metáfora que os apaixonados conseguem dizer do amor. Falando da conversa amorosa, diz Barthes: "A linguagem é uma pele: esfrego minha linguagem no outro. É como se eu tivesse palavras ao invés 
de dedos, ou dedos na ponta das palavras. Minha linguagem treme de desejo." ( 15) Por fim ele explode na conclusão de que, falar amorosamente, é como "praticar uma relação sem orgasmo".

A partir do mito da origem da humanidade, tenho falado da busca feita pelo ser humano bipartido, de sua outra metade. Uma idéia de completude é veiculada no texto, mas jamais deve servir à idéia de possessividade tão própria da cultura. A posse, opõe-se ao amor. A partir do mito, penso se terá sido apenas para enfraquecer-nos, que Zeus dividiu os seres andróginos, ou se foi por saber da beleza maior da vida e das relações, quando conseguimos viver como paralelas encantadas, que se encontram depois em espasmos de vida e ternura. A beleza toca o infinito, se pudermos ser como o contato de duas poesias, a fusão de dois devaneios.

Porque qualquer forma de simbiose astixia o amor, faz-se necessário espaço entre os amantes. É esse espaço de liberdade e de individualidade entre os pares amorosos que estrutura e saúde relacional, e que se faz epifania de uma nova suavidade para as relações.

"Que haja espaços na vossa junção. E que os ventos do céu dancem entre vós. Amai-vos um ao outro, mas não façais do amor um grilhão: Que haja, antes, um mar ondulante entre as praias de vossa alma. Dai o vosso coração, mas não o confieis à guarda um do outro.

Pois somente a mãe da Vida pode conter vosso coração.

E vivei juntos, mas não vos aconchegueis demasiadamente: Pois as colunas do Templo erguem-se separadamente.

E o carvalho e o cipreste não crescem à sombra um do outro." (16)

\section{REFERÊNCIAS BIBLIOGRÁFICAS}

1. SILVA, A. C.: Terapia do Sexo e Dinâmica do Casal. Espaço e Tempo, Rio de Janeiro. 1989.

2. JACOB, F: O Jogo dos Possíveis.

3. PLATÃO: Diálogos. Cultrix. São Paulo.

4. BADINTER, E.: Um Amor Conquistado. O Mito do Amor Materno. Nova Fronteira. Rio de Janeiro. 1985.

5. WINE. N.: Pulsão e Inconsciente. A sublimação e o Advento do Sujeito, Zahar, Rio de Janeiro. 1992.

6. : Idem.

7. BATAILLE, G.: Teoria da Religião, Ática, São Paulo. 1993.

$8 . \quad$ : O Erotismo, LPM. Porto Alegre. 1987.

9. VALENÇA, A. M.: O Amor é o Fim do Cerco. O Erotismo em História do Cerco de Lisboa, de José Saramago, Tese mestrado, PUC, Rio Grande do Sul, 1993. 
10. SIBONY, D.: Sedução. O Amor Inconsciente, Brasiliense, São Paulo, 1991.

11. PLATAO: Idem.

12. BACHELARD, G.: O Direito de Sonhar, Difel, São Paulo, 1986.

13. TÁVOLA, A.: Do Amor. Ensaio de Enigma, Nova Fronteira, Rio de Janeiro, 1983.

14. TRINCA. W.: A Etérea Leveza da Experiência, Siciliano, São Paulo, 1991.

15. BARTHES, R.: Fragmentos de um Discurso Amoroso, Francisco Alves, Rio de Janeiro, 1989

16. GIBRAN, K.: O Profota, Record, Rio de Janciro. 